\title{
All-solid-state direct carbon fuel cells with thin yttrium-stabilized-zirconia electrolyte supported on nickel and iron bimetal-based anodes
}

\author{
Fangyong $\mathrm{Yu}^{\mathrm{a}}$, Yapeng Zhang ${ }^{\mathrm{a}}$, Liang $\mathrm{Yu}^{\mathrm{b}}$, Weizi Cai ${ }^{\mathrm{b}}$, Lili Yuan ${ }^{\mathrm{b}}$, Jiang Liu ${ }^{\mathrm{a}, \mathrm{b},{ }^{*} \text {, }}$ \\ Meilin $\mathrm{Liu}^{\mathrm{c}}$
}

\begin{abstract}
:
Solid oxide fuel cells (SOFCs) with thin yttrium-stabilized-zirconia (YSZ) electrolyte supported on composite anode of nickel-iron bimetal and YSZ are prepared and operated directly on Fe-loaded activated carbon fuel, without any liquid medium or purging gas. The composition of the anode is represented as $\mathrm{Ni}_{1-x} \mathrm{Fe}_{x} \mathrm{O}_{\delta}$ $(x=0,0.05,0.1,0.2,0.3)$-YSZ. Experiment result shows that such kind of all-solid-state direct carbon solid oxide fuel cells (DC-SOFCs) perform well at $800{ }^{\circ} \mathrm{C}$,

\footnotetext{
* Corresponding author: Tel: +86202223 6168; fax: +862022236168.

E-mail address: jiangliu@,scut.edu.cn
} 
giving maximum output power densities in the range of $425-529 \mathrm{~mW} \mathrm{~cm}^{-2}$. Similar to the case of a SOFC operated on hydrogen fuel, a small amount of Fe addition into the Ni-based anode can improve the performance of a DC-SOFC and the optimum composition is $x=0.1$. A DC-SOFC with $\mathrm{Ni}_{0.9} \mathrm{Fe}_{0.1} \mathrm{O}_{s}-\mathrm{YSZ}$ anode, loaded with $2.5 \mathrm{~g}$ Fe-loaded activated carbon fuel, is steadily operated at a constant current density of $0.1 \mathrm{~A} \mathrm{~cm}^{-2}$ for $15 \mathrm{~h}$ at $800{ }^{\circ} \mathrm{C}$. The anodes and the DC-SOFCs are characterized through XRD, AC impedance spectroscopy, and SEM measurements. The superior performance of the Fe-added anode is analyzed accordingly.

Keywords: Solid oxide fuel cell; Direct carbon; Nickel-iron composite anode; All-solid-state; Anode-supported

\section{Introduction}

With increasing concern on the global climate change caused by overconsumption of fossil fuels, there is an urgent need for reducing carbon emission. As fossil fuels, especially coal, will still be the major energy source in the foreseeable future, it is desirable to develop novel technologies which can convert chemical energy of fossil fuels to electricity with high efficiency and low emission. Therefore, the direct carbon fuel cell (DCFC), which has been proposed since one and half centuries ago [1], has regained attention due to its high conversion efficiency and concentrated $\mathrm{CO}_{2}$ product which can be sequestrated with low cost [2-5]. The ideal overall electrochemical reaction in a DCFC is

$$
\mathrm{C}+2 \mathrm{O}^{2-}=\mathrm{CO}_{2}+4 \mathrm{e}^{-}
$$


The theoretical electrical conversion efficiency of this reaction is the Gibbs energy change $\Delta G$ divided by its enthalpy change $\Delta H$. As $\Delta G$ is slightly larger than $\Delta H$ in a wide range of temperature, the conversion efficiency is over $100 \%$, meaning some heat from external sources may be directly converted into electricity along with the DCFC operation. In a DCFC, carbon is electrochemically oxidized at the anode chamber. Compared to carbon oxidation through combustion in air, high concentrated $\mathrm{CO}_{2}$ (without $\mathrm{N}_{2}$ ) is produced. Such $\mathrm{CO}_{2}$ can be further sequestrated or utilized in a much lower cost. A report from EPRI of U.S. evaluating the feasibility of DCFC in electricity generation from coal has confirmed the advantages of DCFC over conventional coal fired power plant [6].

DCFCs can be classified into three types, according to different electrolytes: molten hydroxide [7-9], molten carbonate [10-13], and oxygen ion conducting solid oxide [14-22] among which the last one is the only solid state electrolyte. As the activation energy of carbon oxidation is high, a DCFC needs to operate at relatively high temperatures. Any liquid with high temperature is dangerous as it may cause leaking or corrosion destroying the cell system. In this respect, solid state electrolyte is superior to the liquid electrolyte. However, liquid metals [14-16] or molten salts [17-19] have been added to the anode chamber for carbon delivering in solid electrolyte DCFCs. While the liquid material helps in solving the problem of carbon refilling to DCFCs, it diminishes the merit of solid electrolyte. Gür et al. have proposed DCFCs with solid oxide electrolyte, in which coal is provided with Ar or $\mathrm{CO}_{2}$ as carrying or reforming gas [23-25]. In recent years, our group have been 
focusing on developing an all-solid-state direct carbon solid oxide fuel cell (DC-SOFC), which is a SOFC operated on solid carbon directly filled in the cell as fuel, without any liquid medium or purging gas [26-34] (Fig. 1). The reaction mechanism of such DC-SOFCs was first proposed by Nakagawa and Ishida [35] and was lately verified by Xie et al. [31]. According to the mechanism (Fig. 1a), the DC-SOFC operation is driven by the electrochemical oxidation of $\mathrm{CO}$ at the anode

$$
\mathrm{CO}+\mathrm{O}^{2-}=\mathrm{CO}_{2}+2 \mathrm{e}^{-}
$$

The produced $\mathrm{CO}_{2}$ molecules diffuse to the carbon fuel to perform the reverse Boudouard reaction

$$
\mathrm{CO}_{2}+\mathrm{C}=2 \mathrm{CO}
$$

This reaction is favored at high temperatures because $\mathrm{CO}$ dominates the equilibrium gas composition in a $\mathrm{C}-\mathrm{O}$ system that contains excess $\mathrm{C}$. For example, the molar fraction of $\mathrm{CO}$ and $\mathrm{CO}_{2}$ is $89 \%$ and $11 \%$, respectively, at $800{ }^{\circ} \mathrm{C}$. Through reaction (3), more $\mathrm{CO}$ is produced for reaction (2). In such way, carbon fuel is continuously delivered to the anode for the DC-SOFC operation. There is no need for chemical or even physical contact between carbon and the anode. While such DC-SOFC is still at an early stage of development and there are very few researchers reporting on it, there is an accelerated progress. In 2009, Tang et.al. reported a tubular electrolyte-supporting DC-SOFC operated on graphite fuel which gave a peak power density of $9.2 \mathrm{~mW} \mathrm{~cm}^{-2}$ at $800{ }^{\circ} \mathrm{C}$, but the performance dropped rapidly during a stability test [26]. Later on, by utilizing activated carbon instead of graphite as the fuel, a similar DC-SOFC had steadily operated at a current density of $12.5 \mathrm{~mA} \mathrm{~cm}{ }^{-2}$ 
for $37 \mathrm{~h}$, verifying the self-sustainability of a DC-SOFC [27]. The performance of the DC-SOFCs were significantly improved by loading Fe on activated carbon fuel and applying Ag-GDC (gadolinium doped ceria) to the anode to catalyze the Boudouard reaction and the electrochemical oxidation of $\mathrm{CO}$, respectively. A peak power density of $45 \mathrm{~mW} \mathrm{~cm}^{-2}$ was obtained at $800{ }^{\circ} \mathrm{C}$ [28]. Meanwhile, a Ni-ScSZ anode-supported SOFC operated directly on carbon fuel was reported to produce a peak power density of $75 \mathrm{~mW} \mathrm{~cm} \mathrm{~cm}^{-2}$ at $800{ }^{\circ} \mathrm{C}$ [36]. Our group prepared a cone-shaped NiO-YSZ anode-supported three-cell-in-series stack and operated it on Fe-loaded activated carbon fuel and obtained a peak power densities of $465 \mathrm{~mW} \mathrm{~cm}^{-2}$ at $850^{\circ} \mathrm{C}$. The stack was with a total effective area of $5.2 \mathrm{~cm}^{2}$ releasing a total power of $2.4 \mathrm{~W}$ [29]. As the energy density of carbon is high (8935 $\left.\mathrm{mAh} \mathrm{g}^{-1}\right)$, DCFCs are recommended to be a potential high performance battery [30]. Very recently, a variety of efforts have been offered on DC-SOFCs including verifying the mechanism [31], applying different electrolyte materials [32], improving the fuel process [37-41], and operating with coal-based fuels [42-47]. As $\mathrm{CO}$ is the favored product in C-O system with excess C at high temperatures, a DC-SOFC is also developed for gas-electricity co-generation [34]. Nevertheless, the DC-SOFC is still at a very early stage of research and development. There are many aspects to be explored including materials, operating conditions, kinetics, etc.. It is not clear if the materials of SOFCs operated on hydrogen are proper for DC-SOFCs. Most of the reported DC-SOFCs are electrolyte-supporting. Making the electrolyte thin will improve the performance. While there has been research on DC-SOFCs with conventional NiO-YSZ supported 
SOFCs showing good output performance, the operation stability has not been well studied [29].

Many studies have shown that adding a small amount of Fe into the Ni-based anode can improve the SOFC performance operated on hydrogen and hydrocarbon fuels $[48,49]$. This improvement in performance might be related to the increased porosity and triple phase boundary (TPB) of the anode. Ishihara et al. [50] reported that Fe addition in Ni-based anode decreases the activation energy of the anode reaction and changes the $\mathrm{H}_{2}$ oxidation kinetics. However, if the performance of a DC-SOFC with Ni-based anode can be enhanced in this way is still unknown.

In this paper, we report our work on DC-SOFCs with thin YSZ electrolyte supported on nickel and iron bimetal-based anodes. The composition of the anode is optimized. The operation stability and the starting process are also investigated.

\section{Experimental}

\subsection{Anode-supported SOFC preparation}

Nickel and iron bimetal anode-supported SOFCs were prepared through the following steps in sequence: synthesizing the mixed powder of nickel and iron oxides, fabricating anode substrates, coating YSZ electrolyte on the anode substrates, applying cathode on the electrolyte layer, and assembling SOFCs for tests. The details of the process are described as following.

Mixture of nickel oxide and iron oxide, with a composition represented by $\mathrm{Ni}_{1-x} \mathrm{Fe}_{x} \mathrm{O}_{\delta}(x=0,0.05,0.1,0.2,0.3,1)$, was synthesized by glycine-nitrate process 
(GNP) as has been previously reported [51]. First, $\mathrm{Ni}\left(\mathrm{NO}_{3}\right)_{2} \cdot 6 \mathrm{H}_{2} \mathrm{O}$ (A.R., Guangzhou Chemical Factory Co. Ltd., Guangdong, China) and $\mathrm{Fe}\left(\mathrm{NO}_{3}\right)_{3} \cdot 9 \mathrm{H}_{2} \mathrm{O}$ (A.R., Tianjin Kermel Chemical Reagents Co. Ltd., Tianjin, China), with a certain composition, were dissolved in distilled water to form a precursor solution. Then, glycine (A.R., Guangzhou Chemical Factory Co. Ltd., Guangdong, China) with a molar amount 1.5 times of that of the nitrates was dissolved in the solution. The solution was subsequently heated on a hot plate until it auto-ignited and underwent combustion, producing an ash composed of oxide products. The ash was then fired at $800{ }^{\circ} \mathrm{C}$ for 2 $\mathrm{h}$ to remove any possible carbon residues and a powder of $\mathrm{Ni}$ and Fe oxide mixture was finally obtained for anode preparation.

Each of the as-prepared $\mathrm{Ni}_{1-x} \mathrm{Fe}_{x} \mathrm{O}_{\delta}(x=0,0.05,0.1,0.2,0.3)$ powder (with a certain $x$ ), 8 mol\% yttria-stabilized zirconia (99.99\% purity, Tosoh, Japan), and graphite, with a weight ratio of 50:50:10, were mixed in an agate jar through ball milling for $1 \mathrm{~h}$, with zirconia balls as the balling medium and ethanol as the solvent. Then the mixed powder was dried and pressed into pellets with diameter of $20 \mathrm{~mm}$ and thickness of $0.6 \mathrm{~mm}$ under a pressure of $300 \mathrm{MPa}$. The pellets were then pre-sintered at $1100{ }^{\circ} \mathrm{C}$ for $2 \mathrm{~h}$ in air to get the anode substrates.

A thin YSZ electrolyte layer was coated on each of the anode substrates by using dip coating process, which had been conveyed in our previous work [52,53]. The anode/electrolyte bi-layer was sintered at $1400{ }^{\circ} \mathrm{C}$ for $4 \mathrm{~h}$ to densify the YSZ film. A composite cathode paste composed of $1.4 \mathrm{~g} \mathrm{La}_{0.6} \mathrm{Sr}_{0.4} \mathrm{Co}_{0.2} \mathrm{Fe}_{0.8} \mathrm{O}_{3}$ (LSCF, Ningbo Institute of Material Technology \& Engineering) and 0.6 g $\mathrm{Ce}_{0.8} \mathrm{Gd}_{0.2} \mathrm{O}_{1.9}$ (GDC, 
Ningbo Institute of Material Technology \& Engineering) was prepared by mixing the LSCF and GDC powders in an agate motar and grinding the mixture for $3 \mathrm{~h}$ with $3 \mathrm{~g}$ polyviyl butyral (PVB)-terpineol solution (10 wt $\%$ in concentration) as binder $[54,55]$. The same process was used for preparing a pure LSCF paste. A composite LSCF-GDC functional layer and a pure LSCF current collecting layer were sequentially applied on the YSZ electrolyte film by brush painting and then dried and co-sintered at $900{ }^{\circ} \mathrm{C}$ for $4 \mathrm{~h}$. The cathode area of all the single cells was controlled to be the same, $0.5 \mathrm{~cm}^{2}$.

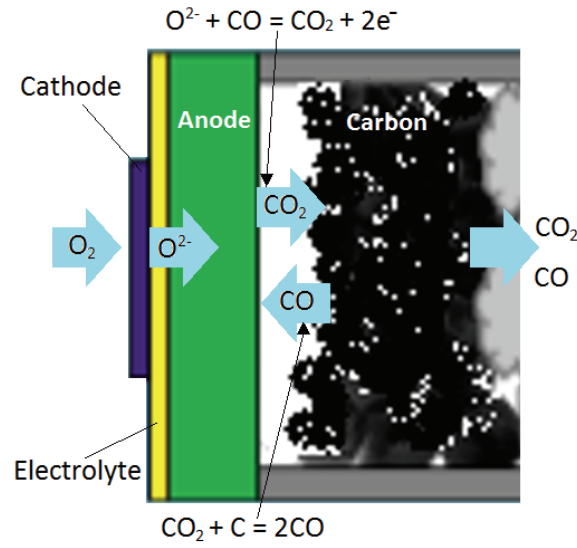

(a)

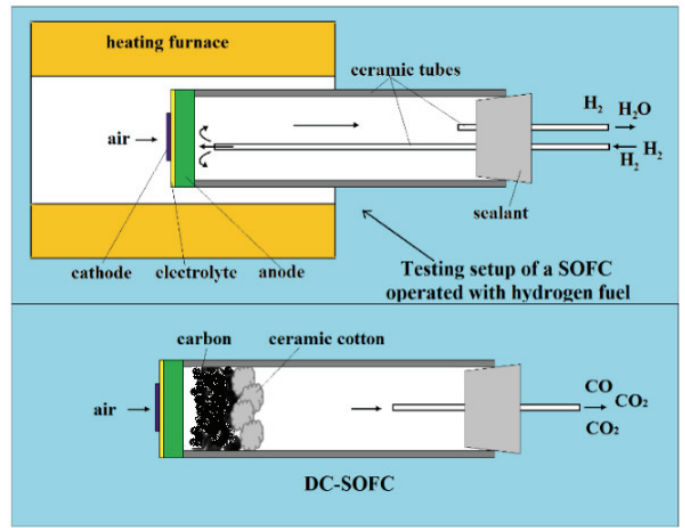

(b)

Fig. 1 Schematic illustration of operation mechanism of a DC-SOFC (a) and testing setup of a SOFC operated on hydrogen (top) and directly on carbon (DC-SOFC) (bottom) (b).

Silver paste (DAD-87, Shanghai Research Institute of Synthetic Resins, Shanghai, China) was used as the current collector for both anode and cathode. Each single SOFC was attached to one end of an alumina tube by using silver paste as a sealing and joining material [56]. Silver wires were attached to the anode and cathode 
of each cell as current leading wires. A tubular furnace was used to provide the temperature environment for the SOFC testing, as shown in Fig. 1b. When hydrogen was used as the fuel, a thin ceramic tube was applied to feed the hydrogen fuel gas in. The emitted gas, composing of produced water and unreacted hydrogen, was let out through another thin ceramic tube.

\subsection{DC-SOFC preparation}

Activated carbon (Aladdin, Shanghai, China; A.R.) was used as the fuel and 5 wt $\%$ Fe was loaded on it to catalyze the Boudouard reaction. The details had been reported in our previous work [28,34]. $\mathrm{Fe}\left(\mathrm{NO}_{3}\right)_{3} \cdot 9 \mathrm{H}_{2} \mathrm{O}$ was dissolved in distilled water with a weight ratio of 1:20. Activated carbon powder was then immerged into the nitrate solution with a weight ratio of $\mathrm{C}: \mathrm{Fe}$ as $95: 5$. Then the mixture was vigorously stirred at $80{ }^{\circ} \mathrm{C}$ to evaporate the water. After that, the mixture was dried at $120{ }^{\circ} \mathrm{C}$ and then heat-treated at $800{ }^{\circ} \mathrm{C}$ for $0.5 \mathrm{~h}$ under flowing $\mathrm{Ar}$ to decompose the nitrate and remove the produced gas. In this way, $5 \mathrm{wt} \% \mathrm{Fe}$ was loaded on the activated carbon in the form of $\mathrm{Fe}_{2} \mathrm{O}_{3}$.

The as-prepared Fe-loaded carbon was filled into the SOFCs to make DC-SOFCs. $2.5 \mathrm{~g}$ of the carbon fuel was placed close to the anode of a SOFC, as shown in Fig. $1 \mathrm{~b}$ (bottom). Some ceramic cotton was stuffed in the tube near the carbon fuel to prevent the solid carbon from flowing away while allowing the produced gas to leave out. Then the open end of the ceramic tube was sealed with a gas leading tube to lead the produced gas out.

\subsection{Characterization}


Both of the original and reduced anode powders were characterized with X-ray powder diffraction (XRD) on a Rigaku D/max-IIIA diffractometer ( $\mathrm{Cu}-\mathrm{K} \alpha$ radiation, operated at $35 \mathrm{kV}, 30 \mathrm{~mA}, \lambda=0.15418 \mathrm{~nm}$ ) at $293 \mathrm{~K}$. The selected $2 \theta$ range was from $20^{\circ}$ to $80^{\circ}$, scanning in increments of $0.02^{\circ}$. The XRD patterns were analyzed and determined with PCPDFWIN 1.10 software, along with previous correlative XRD literature [57]. The electrochemical performance of all the cells were tested using an IviumStat electrochemical analyzer (Ivium Technologies B.V., Netherlands). A four-probe setup was adopted to eliminate the resistance losses from the current leading wires. The current-voltage $(I-V)$ characteristics were tested in the range of $1.2-0.2 \mathrm{~V}$ by linear sweep voltammetry at a scanning rate of $5 \mathrm{mV} / \mathrm{s}$. For impedance measurements, an AC amplitude of $0.01 \mathrm{~V}$ was applied to the sample over a frequency range from $100 \mathrm{kHz}-0.01 \mathrm{~Hz}$ at various temperatures. Impedance spectra plotted in Nyquist representation was fitted to the equivalent circuit model by using the software package ZView (Scribner Associates, Southern Pines, NC, USA). The

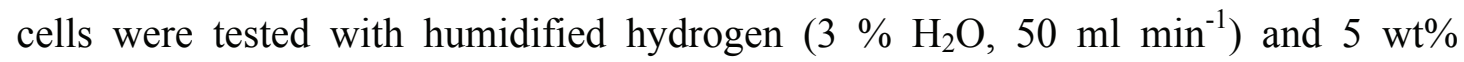
Fe-loaded activated carbon as fuel in the temperature range of $700-800{ }^{\circ} \mathrm{C}$, respectively. The ambient air was used as the oxidant. All the SOFCs, with either hydrogen fed or carbon filled in, were heated from room temperature to $700{ }^{\circ} \mathrm{C}$ followed by dwelling there for $1 \mathrm{~h}$. In such way, the anodes were completely reduced in situ by hydrogen or by in situ produced $\mathrm{CO}$ from the reverse Boudouard reaction. For the DC-SOFCs with NiO-YSZ anode, changes of the resistance were recorded every $50{ }^{\circ} \mathrm{C}$ in the temperature range of $150-800{ }^{\circ} \mathrm{C}$. After that, stability measurement 
for DC-SOFCs with $\mathrm{Ni}_{0.9} \mathrm{Fe}_{0.1} \mathrm{O}_{s}-\mathrm{YSZ}$ and $\mathrm{NiO}-\mathrm{YSZ}$ anodes were taken at $800{ }^{\circ} \mathrm{C}$ under different current densities, respectively. The microstructure of the cells was also characterized after testing using a scanning electron microscope (Carl Zeiss SMT AG, Oberkochen, Germany).

\section{Results and Discussion}

\subsection{Phase identification of the Ni-Fe oxide powders}

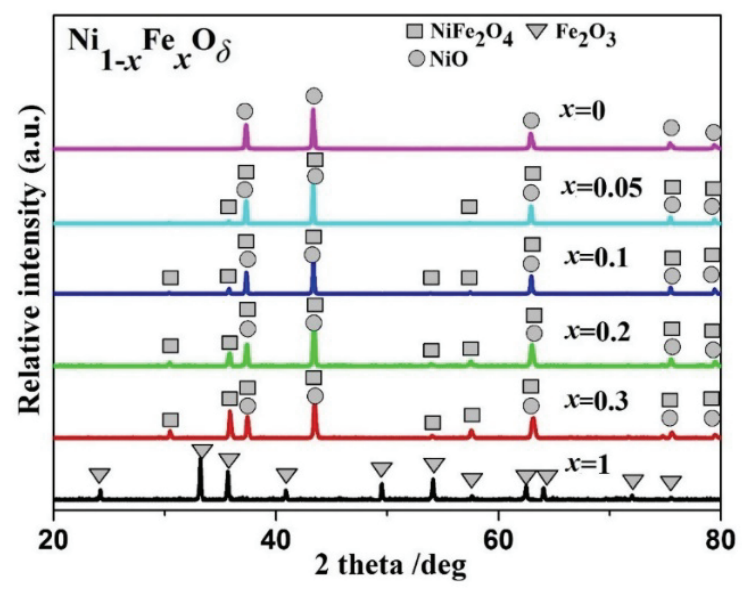

(a)

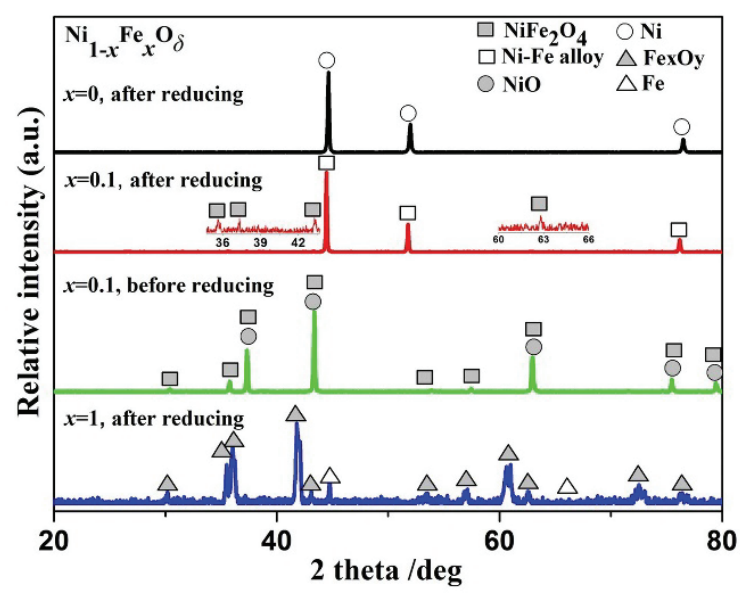

(b)

Fig. 2 - XRD patterns of (a) as-prepared $\mathrm{Ni}_{1-x} \mathrm{Fe}_{x} \mathrm{O}_{s}$ powder and (b) reduced $\mathrm{NiO}, \mathrm{Ni}_{0.9} \mathrm{Fe}_{0.1} \mathrm{O}_{s}$ and 
$\mathrm{Fe}_{2} \mathrm{O}_{3}$ by $\mathrm{CO}$.

Fig. 2a shows the XRD patterns of Ni-Fe oxide powders with different composition. The X-ray spectrum for pure NiO clearly shows a face-centered cubic (FCC) structure, with no second phase detected. Similarly, only hematite $\left(\mathrm{Fe}_{2} \mathrm{O}_{3}\right)$, in a rhombohedral structure, presents in the pure ferric oxide. When a small amount (5-30 mol\%) of ferric oxide is mixed with $\mathrm{NiO}$, the corresponding XRD patterns indicate the coexistence of $\mathrm{NiO}$ and a compound of $\mathrm{Ni}$ and $\mathrm{Fe}\left(\mathrm{NiFe}_{2} \mathrm{O}_{4}\right)$ in a spinel-type structure. Qualitative observation of the relative intensity of the diffraction peaks for the powder samples suggests that $\mathrm{NiO}$ is still the major phase. Note that $\mathrm{Fe}_{2} \mathrm{O}_{3}$ is not well conductive and cannot be reduced completely by carbon monoxide, which facts may increase the resistance of anode and cause degradation of the performance of SOFCs. The calculated lattice parameter for NiO doped with 10 mol\% Fe is 0.41717 $\mathrm{nm}$, smaller than that for pure $\mathrm{NiO}(0.41754 \mathrm{~nm})$. As the ionic radius of $\mathrm{Fe}^{3+}(0.065$ $\mathrm{nm})$ is smaller than that of $\mathrm{Ni}^{2+}(0.069 \mathrm{~nm})$, the decrease of $\mathrm{NiO}$ lattice parameter indicates that some $\mathrm{Fe}$ is doped into the crystal structure of $\mathrm{NiO}$, forming a solid $\mathrm{Ni}_{1-y} \mathrm{Fe}_{y} \mathrm{O}_{\varepsilon}$ solution.

In an attempt to simulate the operating condition of the anode of a DC-SOFC and examine possible correlations between the anode features and the cell performance, we measured the XRD spectra of $\mathrm{Fe}_{2} \mathrm{O}_{3}, \mathrm{NiO}$ and $\mathrm{Ni}_{0.9} \mathrm{Fe}_{0.1} \mathrm{O}_{s}$ after reduction by carbon monoxide, respectively (Fig. 2b). Although there is pure Fe phase in the spectrum of $\mathrm{Fe}_{2} \mathrm{O}_{3}$, the main phase is still dominated by $\mathrm{Fe}$ oxide phases (including 
$\mathrm{Fe}_{2} \mathrm{O}_{3}, \mathrm{Fe}_{3} \mathrm{O}_{4}$ and $\mathrm{FeO}$ ) confirming that $\mathrm{Fe}_{2} \mathrm{O}_{3}$ cannot be completely reduced by carbon monoxide, which is consistent with the theoretical equilibrium calculation (Fig. $\mathrm{S} 1)$. For the spectrum of $\mathrm{Ni}-\mathrm{Fe}$ oxide with $\mathrm{Ni}_{0.9} \mathrm{Fe}_{0.1} \mathrm{O}_{s}$ composition before reduction, all peaks can be identified as $\mathrm{NiFe}_{2} \mathrm{O}_{4}$ spinel and $\mathrm{NiO}$, respectively. After reduction, $\mathrm{NiFe}_{2} \mathrm{O}_{4}$ spinel peaks with low intensities are still detected at $2 \theta$ positions of 35.7 , $37.3,43.3$ and $62.8^{\circ}$. Meanwhile, the diffraction peaks of Ni shift slightly to the lower angles compared with that of pure $\mathrm{Ni}$, indicating that $\mathrm{Ni}-\mathrm{Fe}$ alloy may be formed. According to the Ni-Fe phase diagram, the anticipated phases include $\mathrm{FeNi}_{3}$ and taenite (FeNi) alloy, both are FCC structure and with lattice parameters very close to each other [58].

\subsection{Electrochemical performances of the SOFCs operated on hydrogen fuel}

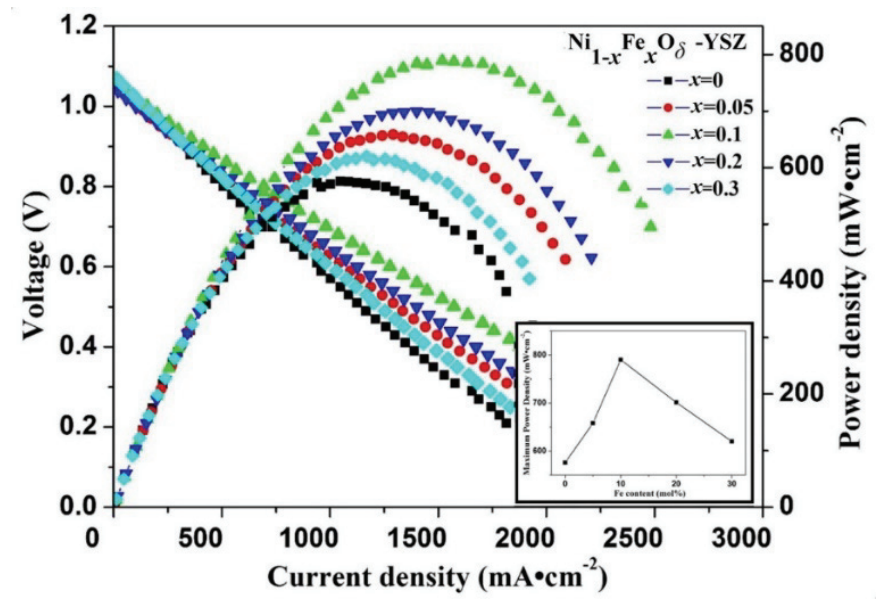

(a) 


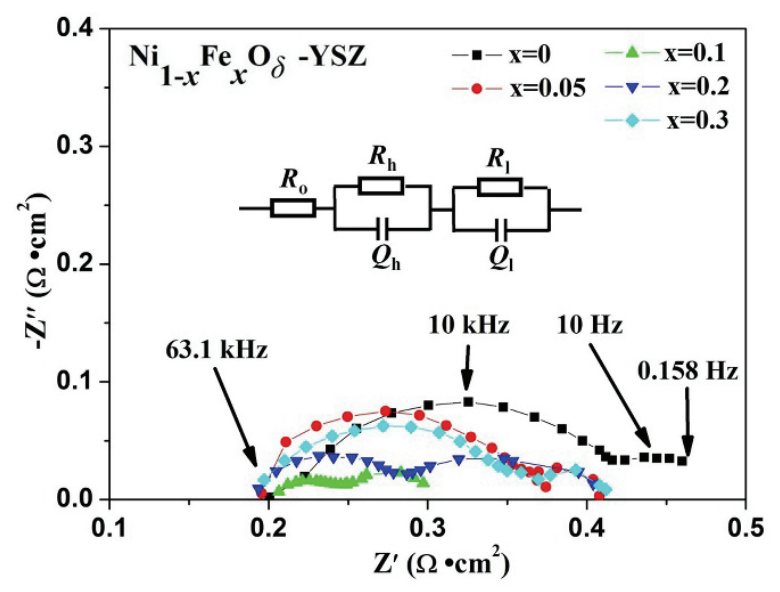

(b)

Fig. 3 - Electrochemical performances of SOFCs with $\mathrm{Ni}_{1-x} \mathrm{Fe}_{x} \mathrm{O}_{o}-\mathrm{YSZ}$ anodes using hydrogen as fuel at $800{ }^{\circ} \mathrm{C}$. (a) Voltage and power density as a function of current density, and maximum power density vs. Fe content in the anode; (b) Impedance spectra under OCV.

The SOFCs with $\mathrm{Ni}_{1-x} \mathrm{Fe}_{x} \mathrm{O}_{s}-\mathrm{YSZ}$ anode of different composition are tested using humidified hydrogen $\left(3 \% \mathrm{H}_{2} \mathrm{O}, 50 \mathrm{ml} \mathrm{min}^{-1}\right)$ as fuel. The electrochemical performances operated at $800{ }^{\circ} \mathrm{C}$ are shown in Fig. 3. As can be seen, the open circuit voltages (OCVs) of all the cells are in the range of $1.04-1.07 \mathrm{~V}$, only $5 \%-3 \%$ lower than the theoretical value $(1.1 \mathrm{~V})$ of a $\mathrm{H}_{2}\left(3 \% \mathrm{H}_{2} \mathrm{O}\right)-\mathrm{O}_{2}$ fuel cell operated at $800{ }^{\circ} \mathrm{C}$, meaning the SOFCs are with relatively dense electrolyte and the cells are well sealed. Fig. 3a shows that the output performances of the SOFCs varies significantly with the anode composition. The maximum power density (MPD) of the cell with conventional NiO-YSZ anode $(x=0)$ is $576 \mathrm{~mW} \mathrm{~cm}^{-2}$. When a small amount of $\mathrm{Fe}$ is added into the anode, the MPD of the corresponding SOFC increases and it reaches the highest up to $790 \mathrm{~mW} \mathrm{~cm}^{-2}$ when $x=0.1$. When the amount of Fe increases further, the performance decreases with Fe addition. Even so, the performance of the cell with 
$x=0.3$ is better than that without any Fe in the anode.

Fig. $3 \mathrm{~b}$ shows the impedance spectra of the hydrogen SOFCs measured at open circuit under $800{ }^{\circ} \mathrm{C}$. The equivalent circuit for the impedance spectra, $R_{0}\left(R_{\mathrm{h}} Q_{\mathrm{h}}\right)\left(R_{1} Q_{1}\right)$, is also shown. Here, $R_{\mathrm{o}}$ is the overall ohmic resistance arisen from the electrolyte, electrodes, contacts at the LSCF-GDC/YSZ and $\mathrm{Ni}_{1-x} \mathrm{Fe}_{x} \mathrm{O}_{s}-\mathrm{YSZ} / \mathrm{YSZ}$ interfaces as well as contacts between the electrodes and current collectors. $R_{\mathrm{h}}$ and $R_{1}$ are the polarization resistances correspond to the high- and low-frequency arcs, respectively, and, $Q_{\mathrm{h}}$ and $Q_{1}$ are the corresponding constant phase elements [59]. As can be seen from the impedance spectra, the total ohmic resistance of all the SOFCs is almost the same $\left(\sim 0.2 \Omega \mathrm{cm}^{2}\right)$ while the polarization resistance changes significantly with the variety of anode composition. As mentioned above, the compositions and preparation conditions for the electrolyte and cathode are identical for all the single cells. Therefore, the total ohmic resistance $\left(R_{\mathrm{o}}\right)$ and cathodic polarization resistance of the SOFCs should be the same, which means that the polarization difference between the SOFCs is mainly caused by the different anodes.

To distinguish the anodic and cathodic polarization resistances, we measured the cathodic polarization resistance through a symmetric electrode cell, of which the cathode material was symmetrically applied on both sides of an YSZ electrolyte disk using the same preparing process for making an SOFC presented in the section 2.1. Impedance of the cell was measured in air, at $800{ }^{\circ} \mathrm{C}$. The resulted polarization resistance is taken as the cathodic polarization of the two cathode/electrolyte interfaces, and the real cathodic polarization resistance is half of the result. The 
measurement was repeated for four times, and an average cathodic polarization resistance of $R_{\mathrm{c}}=0.065 \Omega \mathrm{cm}^{2}$ was obtained (Fig. S4). The anodic polarization resistance $R_{\mathrm{a}}$ of each cell is the difference between the overall polarization resistance and the cathodic one.

Table 1 listed the data obtained from the impedance measurements, including the ohmic resistance $R_{0}$, the resistances respectively fitted from the high and low frequency arcs, $R_{\mathrm{h}}$ and $R_{\mathrm{l}}$, the total resistance $R_{\mathrm{t}}$, and the anodic polarization resistance $R_{\mathrm{a}}$. The anodic polarization is obtained by subtracting the ohmic resistance $R_{\mathrm{o}}$ and the cathodic polarization $R_{\mathrm{c}}\left(0.065 \Omega \mathrm{cm}^{2}\right)$. The data for the DC-SOFCs, which will be discussed later, are also listed in the table. For the SOFCs operated on $\mathrm{H}_{2}\left(\mathrm{H}_{2}-\mathrm{SOFC}\right)$, the anodic polarization resistance decreases with the Fe content added in the anode when the content is less than $10 \mathrm{~mol} \%(x<0.1)$, while it increases when the content is larger than $10 \mathrm{~mol} \%(x>0.1)$. The lowest anodic polarization resistance $(\sim 0.016 \Omega$ $\left.\mathrm{cm}^{2}\right)$ is from the SOFC with the anode of $x=0.1\left(\mathrm{Ni}_{0.9} \mathrm{Fe}_{0.1} \mathrm{O}_{s}-\mathrm{YSZ}\right)$ and the highest $\left(\sim 0.194 \Omega \mathrm{cm}^{2}\right)$ is from the SOFC without any Fe added into the anode. These are consistent with the output performance result. The optimum composition $(x=0.1)$ obtained here is also the same with the results of a hydrogen SOFC reported by Ding et al. [60].

Table 1. Impedance data for different cells measured under OCV at $800{ }^{\circ} \mathrm{C}\left(\Omega \mathrm{cm}^{2}\right)$

\begin{tabular}{|c|c|c|c|c|c|c|}
\hline SOFC & Fe & Ohmic & High & Low & Total & Anodic \\
& content & resistance & frequency & frequency & resistance & polarization \\
\hline
\end{tabular}




\begin{tabular}{|c|c|c|c|c|c|c|}
\hline & $(\mathrm{mol} \%)$ & $R_{\mathrm{o}}$ & $R_{\mathrm{h}}$ & $R_{1}$ & $R_{\mathrm{t}}$ & resistance $R_{\mathrm{a}}$ \\
\hline \multirow{5}{*}{$\mathrm{H}_{2}$-SOFC } & 0 & 0.201 & 0.215 & 0.044 & 0.460 & 0.194 \\
\hline & 5 & 0.196 & 0.178 & 0.034 & 0.408 & 0.147 \\
\hline & 10 & 0.206 & 0.042 & 0.049 & 0.297 & 0.016 \\
\hline & 20 & 0.194 & 0.093 & 0.117 & 0.404 & 0.145 \\
\hline & 30 & 0.197 & 0.172 & 0.043 & 0.412 & 0.150 \\
\hline \multirow{5}{*}{ DC-SOFC } & 0 & 0.208 & 0.260 & 0.058 & 0.525 & 0.242 \\
\hline & 5 & 0.211 & 0.138 & 0.124 & 0.473 & 0.197 \\
\hline & 10 & 0.205 & 0.032 & 0.141 & 0.378 & 0.108 \\
\hline & 20 & 0.216 & 0.077 & 0.133 & 0.426 & 0.145 \\
\hline & 30 & 0.215 & 0.305 & 0.130 & 0.650 & 0.370 \\
\hline
\end{tabular}

Note that ferric oxides cannot be completely reduced even in the atmosphere of hydrogen (Fig. S2). As stated before, Fe exists in the form of Ni-Fe alloy and $\mathrm{NiFe}_{2} \mathrm{O}_{4}$ spinel in the anode after reducing, as shown in Fig. 2b. While $\mathrm{NiFe}_{2} \mathrm{O}_{4}$ spinel is not as conductive as Fe or Ni metal, the ohmic resistance of the SOFCs seems not affected by the Fe addition. The reason of this fact might be that the amount of Fe addition is too small to affect the total ohmic resistance of the SOFCs which is dominated by that of the YSZ electrolyte.

\subsection{Electrochemical performance of DC-SOFCs}

According to the chemical equilibrium theory of thermodynamics, $\mathrm{CO}$ is the 
favored product in a $\mathrm{C}-\mathrm{O}$ system with excess amount of $\mathrm{C}$, at high temperatures, as in the case of DC-SOFCs. Both theory and experiment have confirmed that $\mathrm{NiO}$ can be reduced by $\mathrm{CO}$ and transformed into Ni (Fig. S3). While ferric oxide cannot be completely reduced even by hydrogen who is more reducing than $\mathrm{CO}$, the existence of ferric oxides does not increase the resistance of the SOFCs because the content fraction of $\mathrm{Fe}$ in the Ni-based anode is too little to affect the total resistance. Therefore, the DC-SOFCs can be operated without any purging gas to pre-reduce the anode (mainly $\mathrm{NiO}$ ). Moreover, there is no need to expel the air, which can help starting the operation, within the DC-SOFCs. In other words, the anode can be reduced by in situ produced $\mathrm{CO}$ in a DC-SOFC at high temperatures through the following way: The oxygen in the residual air reacts with the carbon fuel to produce $\mathrm{CO}$, which diffuses to the anode to reduce $\mathrm{NiO}$

$$
\mathrm{NiO}+\mathrm{CO}=\mathrm{Ni}+\mathrm{CO}_{2}
$$

The produced $\mathrm{CO}_{2}$ diffuses to the carbon fuel to perform the Boudouard reaction (3) producing more $\mathrm{CO}$ for the reaction (2). Fig. 4 shows the resistance decreasing with temperature for a DC-SOFC with NiO-YSZ anode operated without any purging gas. Its ohmic and total resistances are 0.208 and $0.525 \Omega \mathrm{cm}^{2}$, respectively, at $800{ }^{\circ} \mathrm{C}$. The result is reasonable for a NiO-YSZ anode-supported SOFC and consistent with the SOFC tested with hydrogen, suggesting the $\mathrm{NiO}$ is completely reduced by in situ produced CO with the DC-SOFC operation. This fact is of significant importance for DC-SOFCs as it offers the advantage of configuration simplification that avoiding any purging gas equipment. 


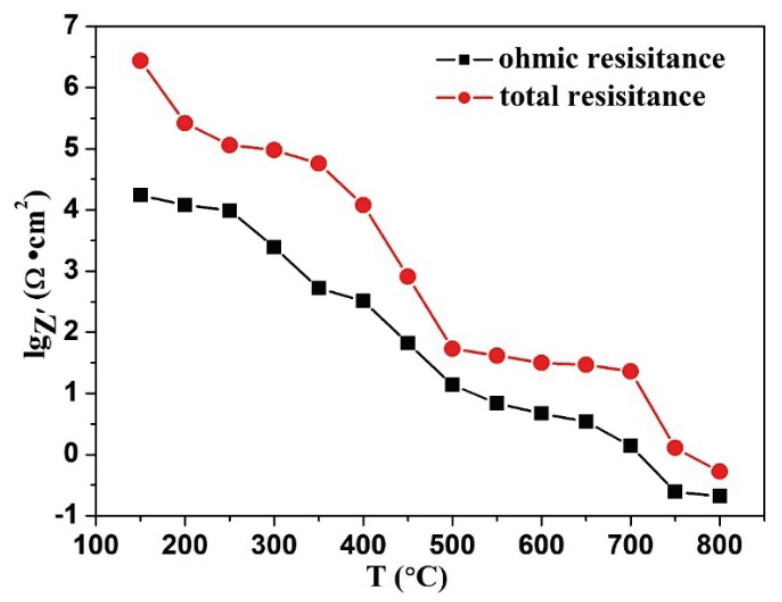

Fig. 4 - The changes of the resistance of a DC-SOFC with NiO-YSZ anode measured under OCV in the temperature range of $150-800{ }^{\circ} \mathrm{C}$.

Fig. 5 shows the electrochemical performances of the DC-SOFCs with different $\mathrm{Ni}_{1-x} \mathrm{Fe}_{x} \mathrm{O}_{s}-\mathrm{YSZ}$ anodes. The OCVs are around $0.94 \mathrm{~V}$, which is about $10 \%$ lower than the theoretical value $(1.04 \mathrm{~V})$ of a DC-SOFC operated at $800{ }^{\circ} \mathrm{C}$, calculated from the thermodynamic equilibrium theory [31]. This deviation from theoretical expectation is more than two times of those for the SOFCs operated on hydrogen. While there are variety of factors affecting the OCVs [37,61-63], it is not proper to simply attribute the lower OCVs to some gas leaking of the SOFCs because these SOFCs work well with hydrogen who is more readily to cause leaking due to its smaller molecule size. Considering higher OCVs, which are comparable to that of a SOFC operated on hydrogen $(1.1 \mathrm{~V})$, have been obtained with tubular DC-SOFCs whose exhaust was let out by small leading tubes (with small space behind the anode) in our previous work $[28,29,31]$, the lower OCVs in the present work may be related to the configuration as shown in Fig. $1 \mathrm{~b}$ (bottom), in which large space is behind of 
the carbon fuel. Even if both the electrochemical oxidation of CO (2) and the Boudouard reaction (3) are spontaneous, half of the $\mathrm{CO}$ produced by reaction (3) may diffuse to the large space instead of to the anode, causing dilution of $\mathrm{CO}$ for reaction (2) and resulting in lower OCV. Despite all this, relatively high performance are still obtained from the DC-SOFCs, as shown in Fig. 5a.

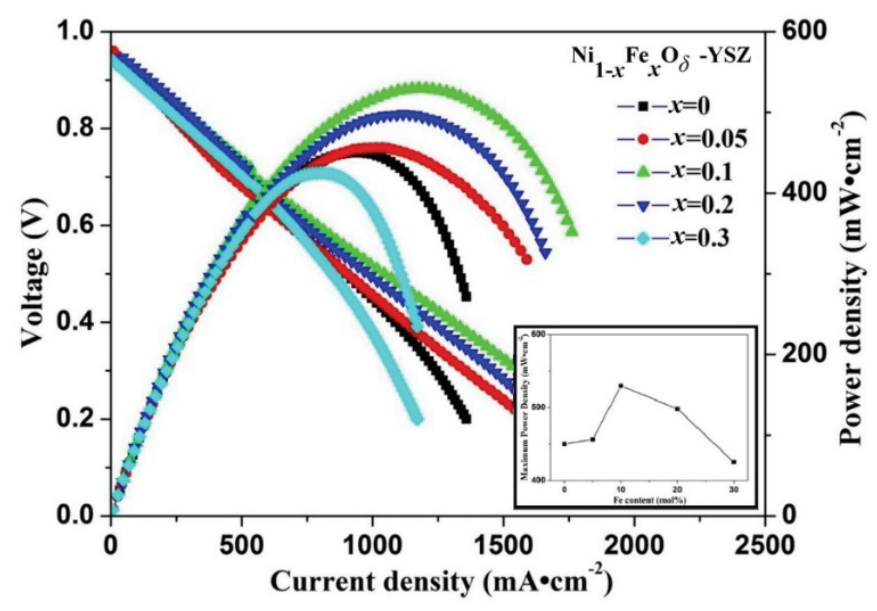

(a)

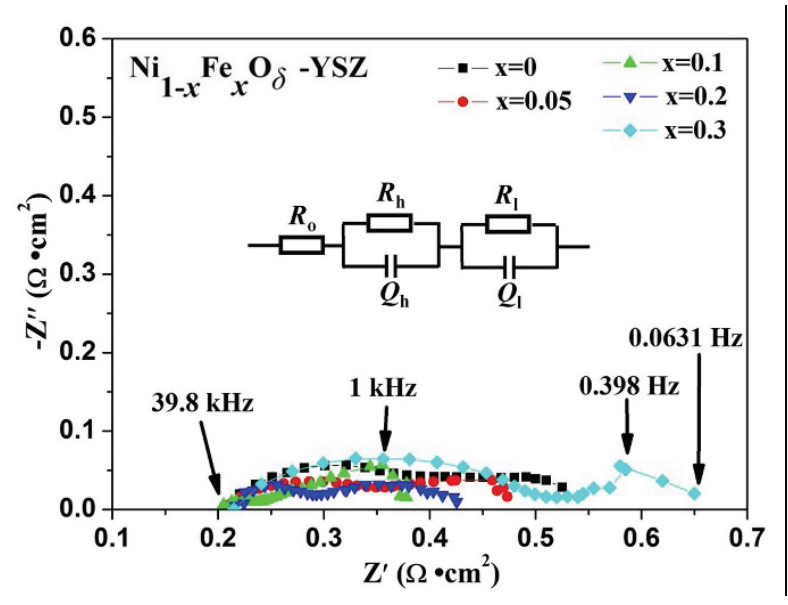

(b)

Fig. 5 - Electrochemical performances of DC-SOFCs with $\mathrm{Ni}_{1-x} \mathrm{Fe}_{x} \mathrm{O}_{s}-\mathrm{YSZ}$ anodes at $800{ }^{\circ} \mathrm{C}$. (a) Voltage and power density as a function of current density, and maximum power density vs. Fe content; (b) Impedance spectra under OCV. 
Similar to the situation of SOFCs operated on hydrogen, the performances of the DC-SOFCs are dependent on the anode composition. Fig. 5a shows that MPD increases with a small amount of Fe addition. Then it reaches the highest $(529 \mathrm{~mW}$ $\mathrm{cm}^{-2}$ ) when the content of $\mathrm{Fe}$ is $x=0.1$, the same with the optimum composition for the SOFCs operated on hydrogen. After that, the MPD decreases with the adding amount of Fe. Note that, unlike the situation of hydrogen SOFCs, the performance of the DC-SOFC with the anode of $x=0.3\left(425 \mathrm{~mW} \mathrm{~cm}^{-2}\right)$ is poorer than that without $\mathrm{Fe}$ addition in the anode $\left(456 \mathrm{~mW} \mathrm{~cm}^{-2}\right)$. This may be caused by some densification of the anode as it can be clearly seen from Fig. 5a that there is an obvious performance decrease for the cell of $x=0.3$, arisen from concentration polarization at high current density.

The impedance spectra of the DC-SOFCs operated at OCVs under $800{ }^{\circ} \mathrm{C}$ are shown in Fig. 5b. The parameters derived from the impedance spectra are listed in Table 1. Similar to the situation of the SOFCs on hydrogen, the ohmic resistances of all the DC-SOFCs are around $0.2 \Omega \mathrm{cm}^{2}$, while the polarization resistances vary with different composition of the SOFC anodes. Comparing Fig. 5a with Fig. 5b, it is found that higher output performance of DC-SOFC corresponds to lower polarization resistance. It can be seen from Table 1 that the anodic polarization resistance of a DC-SOFC is larger than that of a hydrogen SOFC. The reaction occurs at the anode of a DC-SOFC is the electrochemical oxidation of CO which is less active than that of $\mathrm{H}_{2}$. Besides, $\mathrm{CO}$ molecule is much bigger and heavier than $\mathrm{H}_{2}$, and its diffusion rate 
through the porous anode support is slower, thus leading to higher concentration polarization of the anode reaction. As a result, the overall polarization resistance of the DC-SOFC doubles that of the corresponding SOFC operated on hydrogen. Furthermore, the effect of the bigger reactant molecules on the concentration polarization is also clearly seen from the obvious deviation of the $I-V$ curve for $x=0.3$ at high electrical current (Fig. 5a).

According to Table 1 , the highest anodic polarization resistance $\left(0.370 \Omega \mathrm{cm}^{2}\right)$ goes to the DC-SOFC with the anode of $x=0.3$ while the lowest $\left(0.108 \Omega \mathrm{cm}^{2}\right)$ goes to that of $x=0.1$. Table 1 also shows that all the anodic polarizations of the DC-SOFCs are significantly larger than the cathodic value $\left(0.065 \Omega \mathrm{cm}^{2}\right)$, indicating that the cathode charge transfer reaction is faster than the $\mathrm{CO}$ oxidation reaction at the anode.

\subsection{Stability/discharging characteristics of DC-SOFCs}

In the present work, carbon is loaded in the SOFCs statically. If the carbon is taken as an active material, the DC-SOFC can be viewed as a primary battery $[29,30]$, which might be applied as an alternative to lead-acid battery or small size diesel electricity generator (which also operates at high temperature but with low efficiency and loud noise). The discharging characteristics of a DC-SOFC as a battery also represents the operating stability of it as a fuel cell. Fig. 6 shows the discharging characteristics or operating stability of the DC-SOFCs with NiO-YSZ and $\mathrm{Ni}_{0.9} \mathrm{Fe}_{0.1} \mathrm{O}_{s}-\mathrm{YSZ}$ anodes operated under current densities of $0.1,0.2$ and $0.4 \mathrm{~A} \mathrm{~cm}^{-2}$, respectively, at $800{ }^{\circ} \mathrm{C}$. Operating at a certain constant current density, the DC-SOFC with Fe-added anode gives more stable discharge voltage plateau than that without Fe 
in the anode does. It can be seen from Fig. 6 that, while the DC-SOFC with NiO-YSZ anode operates longer time than the one with Fe-added anode does before reaching zero voltage, it degrades continuously all the way during the operation. In other words, there is not a discharging plateau for the DC-SOFC with NiO-YSZ anode.

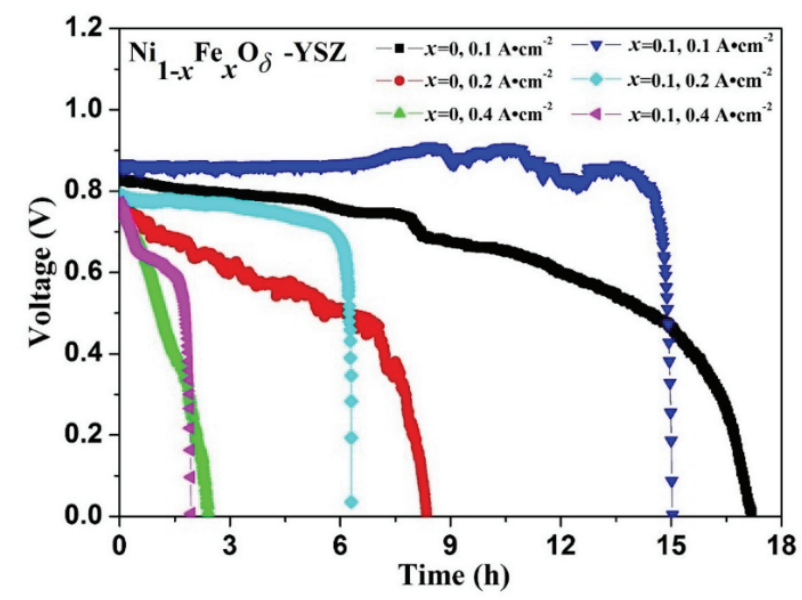

Fig. 6 - Stability/discharging characteristics of DC-SOFCs with $\mathrm{Ni}_{0.9} \mathrm{Fe}_{0.1} \mathrm{O}_{s}-\mathrm{YSZ}$ and NiO-YSZ anodes under different current densities at $800{ }^{\circ} \mathrm{C}$.

If the time of a voltage degradation of $10 \%$ is taken as the life time (or discharging time) of a DC-SOFC, then the life time of the DC-SOFC with NiO-YSZ anode is much shorter than that with Fe-added anode. The life time of the $\mathrm{Ni}_{0.9} \mathrm{Fe}_{0.1} \mathrm{O}_{s}-\mathrm{YSZ}$ anode DC-SOFC operated at $0.1,0.2$ and $0.4 \mathrm{~A} \mathrm{~cm}^{-2}$ is $15 \mathrm{~h}, 6 \mathrm{~h}$ and $1.7 \mathrm{~h}$, corresponding to a discharging capacity of $1.5,1.2$ and $0.68 \mathrm{~A} \mathrm{~h}$, respectively; while that of the NiO-YSZ anode DC-SOFC is only $7 \mathrm{~h}, 1 \mathrm{~h}$ and $0.5 \mathrm{~h}$, corresponding to $0.7,0.2$ and $0.2 \mathrm{~A} \mathrm{~h}$, respectively. It can be seen that higher operating current leads to lower discharging capacity. This feature of the DC-SOFCs is consistent with conventional batteries although the discharging mechanism of the two kinds of 
cell/battery is different. Regarding to the DC-SOFCs, the CO production rate from the reverse Boudouard reaction is decreasing with operating time as the carbon is being consumed and then its surface area for the reaction is shrinking. Once the carbon remained cannot provide sufficient reaction area for the reverse Boudouard reaction to provide the $\mathrm{CO}$ concentration for maintaining the operating current, the performance of the DC-SOFC drops rapidly. Larger reaction area, thus more remained carbon, is needed to guarantee larger operating current. Therefore, less carbon is consumed during the complete discharging process with higher operating current, resulting in smaller discharging capacity. Despite the evidence found in our previous work that more $\mathrm{CO}_{2}$ is in the exhausted gas composition (mixture of $\mathrm{CO}$ and $\mathrm{CO}_{2}$ ) with higher operating current [31], which may raise the discharging efficiency of the DC-SOFC, the effect of reaction area seems dominating.

As the carbon fuel for the two kinds of DC-SOFCs is the same, the difference between the stability must be related to the anode. As discussed above, a small amount of $\mathrm{Fe}$ added in the anode may significantly improve the performance of a DC-SOFC. As the reaction occurring at the anode is the electrochemical oxidation of $\mathrm{CO}$ (2), the added Fe must be active in catalyzing reaction (2). The stable discharging voltage plateau given by the DC-SOFC with Fe-added anode also suggest that the Boudouard reaction (3) is fast enough to provide sufficient $\mathrm{CO}$ for reaction (2). Thus the degradation in voltage during discharging of the DC-SOFC with NiO-YSZ anode, without any Fe catalyst, should be attributed to the relatively slow rate of reaction (2). As a consequence, a proper amount of Fe added in the NiO-YSZ anode can improve 
the output performance and operating stability (or life time) of a DC-SOFC through catalyzing the electrochemical oxidation of $\mathrm{CO}$ at the anode.

\subsection{SEM analysis}

It can be known from the above discussion that some performance degradation of the DC-SOFCs may be related to concentration polarization which is generally dependent on size and mass of the reactant molecule as well as porosity and pore size of the electrodes. Fig. 7 shows the SEM images of the section of the DC-SOFCs with different $\mathrm{Ni}_{1-x} \mathrm{Fe}_{x} \mathrm{O}_{s}-\mathrm{YSZ}$ anodes after stability test ( $x=0$ (a), $x=0.05$ (b), $x=0.1$ (c), $x=0.2$ (d) and $x=0.3(\mathrm{e}))$. For all the DC-SOFCs, the YSZ electrolyte is dense while the electrodes are porous. Typically, the thickness of the YSZ electrolyte layer is 27 $\mu \mathrm{m}$, the cathode is $35 \mu \mathrm{m}$, as shown in Fig. 7a. In the NiO-YSZ anode $(x=0)$, there are scattering pores but both the porosity and the pore size are not large. When a small amount $(x=0.05, x=0.1)$ of $\mathrm{Fe}$ is added into the anode, the porosity and the pore size increase. It can be clearly seem from Fig. 7 that the anode of $x=0.1$ is the most porous while the anodes with $x=0$ and $x=0.3$ are relatively dense, which are consistent with the porosity result in Fig. S5. These evidences can well explain the above experimental results including the output performance, the impedance spectra, and the discharging characteristics. 


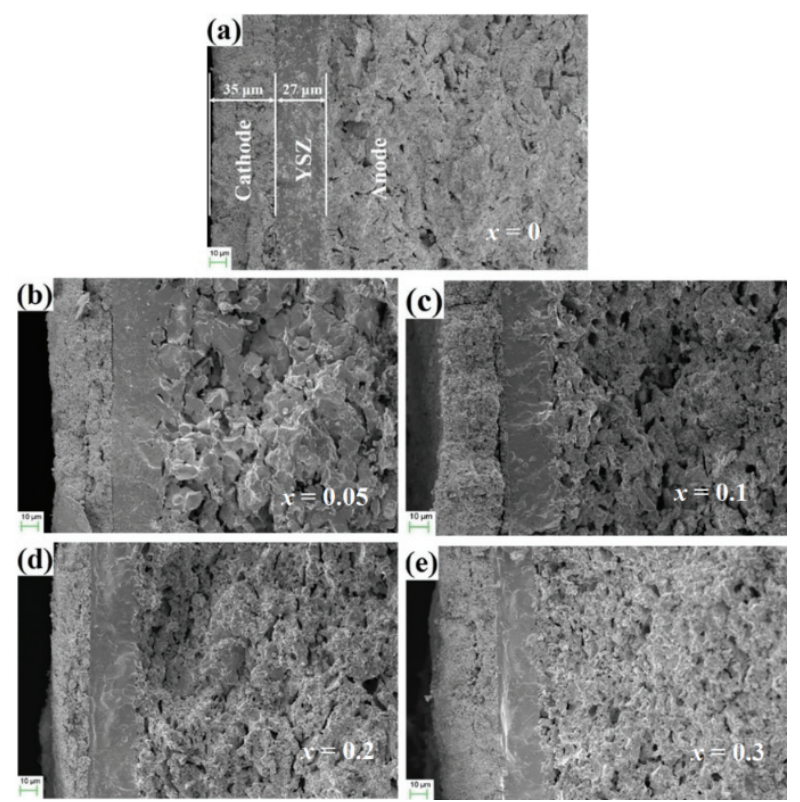

Fig. 7 - SEM images of the DC-SOFCs with $\mathrm{Ni}_{1-x} \mathrm{Fe}_{x} \mathrm{O}_{5}-\mathrm{YSZ}$ anodes after stability/discharging

$$
\text { test: (a) } x=0 \text {; (b) } x=0.05 \text {; (c) } x=0.1 \text {; (d) } x=0.2 \text {; (e) } x=0.3 \text {. }
$$

A reasonable resistivity value of $\mathrm{YSZ}$ at $800{ }^{\circ} \mathrm{C}$ is $50 \Omega \mathrm{cm}$ [64], which can be applied to estimate the ohmic resistance of the YSZ electrolyte in the present work. A thickness of $27 \mu \mathrm{m}$ of the YSZ leads to an area specific resistance of $\sim 0.14 \Omega \mathrm{cm}^{2}$. This confirms the assumption that the measured ohmic resistance of all the SOFCs, $\sim 0.2 \Omega \mathrm{cm}^{2}$, is dominated by the ohmic resistance of the electrolyte.

\section{Conclusions}

In summary, $\mathrm{Ni}_{1-x} \mathrm{Fe}_{x} \mathrm{O}_{s}$-YSZ anode-supported thin YSZ electrolyte SOFCs can be directly operated on solid carbon fuel, without any liquid medium and purging gas. The electrochemical performance of such kind of all-solid-state DC-SOFCs increases with Fe addition when $x \leq 0.1$ while it decreases when $x \geq 0.1$. The DC-SOFC with $\mathrm{Ni}_{0.9} \mathrm{Fe}_{0.1} \mathrm{O}_{s}-\mathrm{YSZ}$ anode reveals the highest MPD of $529 \mathrm{~mW} \mathrm{~cm}^{-2}$ and the lowest 
polarization resistance of $0.173 \Omega \mathrm{cm}^{2}$ at $800{ }^{\circ} \mathrm{C}$. As a comparison, the DC-SOFC with traditional NiO-YSZ anode only gives an MPD of $456 \mathrm{~mW} \mathrm{~cm}^{-2}$ and a polarization resistance as large as $0.317 \Omega \mathrm{cm}^{2}$. In addition, relatively ideal discharging plateaus are obtained from the DC-SOFC with $\mathrm{Ni}_{0.9} \mathrm{Fe}_{0.1} \mathrm{O}_{s}-\mathrm{YSZ}$ anode operated at variety of constant current densities while the voltages keep decreasing with operating time for the DC-SOFC without Fe in the anode. With $2.5 \mathrm{~g} 5 \mathrm{wt} \%$ Fe-loaded activated carbon filled in, the DC-SOFC of $x=0.1$ is steadily operated at a constant current density of $0.1 \mathrm{~A} \mathrm{~cm}^{-2}$ for $15 \mathrm{~h}$, revealing a stable voltage plateau of $0.86 \mathrm{~V}$ at $800{ }^{\circ} \mathrm{C}$. Both electrochemical performance and SEM measurement results suggest that the superior performance of the DC-SOFCs with a proper amount of Fe addition into the anode is not only related to catalyze the electrochemical oxidation reaction of $\mathrm{H}_{2} / \mathrm{CO}$ in the anode, but also the increased porosity. In other words, a proper amount of Fe addition can reduce the activation energy of the anode reaction and the concentration polarization of the corresponding DC-SOFCs, resulting in the performance improvement. Compared to nickel, iron is nontoxic and low cost. Therefore, the present work has provided an option for choosing anode materials for DC-SOFCs with high performance, low cost, and environmental friendliness.

\section{Acknowledgement}

This work was supported by the National Science Foundation of China (NSFC, No. 21276097), the Special Funds of Guangdong Province Public Research and Ability Construction (No. 2014A010106008), Guangdong Innovative and 
Entrepreneurial Research Team Program (2014ZT05N200), and Program of Excellent Ph.D Thesis Authors of Guangdong Province.

\section{References}

[1] Rady AC, Giddey S, Badwal SPS, Ladewig BP, Bhattacharya S. Review of fuels for direct carbon fuel cells. Energy \& Fuels 2012;26:1471-88.

[2] Dicks AL. The role of carbon in fuel cells. J Power Sources 2006;156:128-41.

[3] Cao DX, Sun Y, Wang GL. Direct carbon fuel cell: fundamentals and recent developments. J Power Sources 2007;167:250-7.

[4] Giddey S, Badwal SPS, Kulkarni A, Munnings C. A comprehensive review of direct carbon fuel cell technology. Prog Energ Combust 2012;38:360-99.

[5] Gür TM. Critical review of carbon conversion in "carbon fuel cells". Chem Rev 2013;113:6179-206.

[6] Carlson EJ. Assessment of a novel direct coal conversion fuel cell technology for electric utility markets. EPRI report 1013362 (2006).

[7] Zecevic S, Patton EM, Parhami P. Carbon-air fuel cell without a reforming process. Carbon 2004;42:1983-93.

[8] Zecevic S, Patton EM, Parhami P. Direct electrochemical power generation from carbon in fuel cells with molten hydroxide electrolyte. Chem Eng Commun 2005;192:1655-70.

[9] Kacprzak A, Kobylecki R, Bis Z. Influence of temperature and composition of $\mathrm{NaOH}-\mathrm{KOH}$ and $\mathrm{NaOH}-\mathrm{LiOH}$ electrolytes on the performance of a direct carbon 
fuel cell. J Power Sources 2013;239:409-14.

[10] Lee AC, Mitchell RE, Gür TM. Thermodynamic analysis of gasification-driven direct carbon fuel cells. J Power Sources 2009;194:774-85.

[11] Jain SL, Nabae Y, Lakeman BJ, Pointon KD, Irvine JTS. Solid state electrochemistry of direct carbon/air fuel cells. Fuel Cells Bull 2008;2008:10-3.

[12] Pointon K, Lakeman B, Irvine J, Bradley J, Jain S. The development of a carbon-air semi fuel cell. J Power Sources 2006;162:750-6.

[13] Cooper JF, Selman R. Electrochemical oxidation of carbon for electric power generation: a review. ECS Trans 2009;19:15-25.

[14] Jayakumar A, Kungas R, Roy S, Javadekar A, Buttrey DJ, Vohs JM. A direct carbon fuel cell with a molten antimony anode. Energy \& Environ Sci 2011;4:4133-37.

[15] Giddey S, Kulkarni A, Munnings C, Badwal SPS. Composite anodes for improved performance of a direct carbon fuel cell. J Power Sources 2015;284:122-9.

[16] Cao T, Wang H, Shi Y, Cai N. Direct carbon fuel conversion in a liquid antimony anode solid oxide fuel cell. Fuel 2014:135:223-7.

[17] Chien AC, Irvine JTS. Molten Salts Chemistry: From Lab to Applications $2013 ; 403-14$.

[18] Cantero-Tubilla B, Xu C, Zondlo JW, Sabolsky K, Sabolsky EM. Investigation of anode configurations and fuel mixtures on the performance of direct carbon fuel cells (DCFCs). J Power Sources 2013;238:227-35. 
[19] Bonaccorso AD, Irvine JTS. Development of tubular hybrid direct carbon fuel cell. Int J Hydrogen Energy 2012;37:19337-44.

[20] Dudek M, Tomov RI, Wang C, Glowacki BA, Tomczyk P, Socha RP. Feasibility of direct carbon solid oxide fuels cell (DC-SOFC) fabrication by inkjet printing technology. Electrochim Acta 2013;105:412-8.

[21] Rady AC, Giddey S, Kulkarni A, Badwal SPS, Bhattacharya S, Ladewig BP. Direct carbon fuel cell operation on brown coal. Appl Energy 2014;120:56-64.

[22] Yu X, Shi Y, Wang H, Cai N, Li C, Ghoniem AF. Using potassium catalytic gasification to improve the performance of solid oxide direct carbon fuel cells: Experimental characterization and elementary reaction modeling. J Power Sources 2014;252:130-7.

[23] Gür TM, Huggins RA. Direct electrochemical conversion of carbon to electrical energy in a high temperature fuel cell. J Electrochem Soc 1992;139:L95-7.

[24] Gür TM, Homel M, Virkar AV. High performance solid oxide fuel cell operating on dry gasified coal. J Power Sources 2010;195:1085-90.

[25] Li S, Lee AC, Mitchell RE, Gür TM. Direct carbon conversion in a helium fluidized bed fuel cell. Solid State Ionics 2008;179:1549-52.

[26] Tang YB, Liu J, Sui J. A novel direct carbon solid oxide fuel cell. ECS Trans 2009;25:1109-14.

[27] Tang YB, Liu J. Fueling solid oxide fuel cells with activated carbon. Acta Phys Chim Sin 2010;26:1191-4.

[28] Tang YB, Liu J. Effect of anode and Boudouard reaction catalysts on the 
performance of direct carbon solid oxide fuel cells. Int J Hydrogen Energ 2010;35:11188-93.

[29] Bai YH, Liu Y, Tang YB, Xie YM, Liu J. Direct carbon solid oxide fuel cell—a potential high performance battery. Int J Hydrogen Energ 2011;36:9189-94.

[30] Liu J, Liu Y, Tang YB, Bai YH. A direct carbon solid oxide fuel cell power system. Chinese Patent: ZL201110008698.8 (2013).

[31] Xie YM, Tang YB, Liu J. A verification of the reaction mechanism of direct carbon solid oxide fuel cells. J Solid State Electrochem 2013;17:121-7.

[32] Zhang L, Xiao J, Xie YM, Tang YB, Liu J, Liu ML. Behavior of strontium-and magnesium-doped gallate electrolyte in direct carbon solid oxide fuel cells. J Alloys Compd 2014;608:272-7.

[33] Cai WZ, Zhou Q, Xie YM, Liu J. A facile method of preparing Fe-loaded activated carbon fuel for direct carbon solid oxide fuel cells. Fuel 2015;159:887-93.

[34] Xie YM, Cai WZ, Xiao J, Tang YB, Liu J, Liu ML. Electrochemical gas-electricity cogeneration through direct carbon solid oxide fuel cells. J Power Sources $2015 ; 277: 1-8$.

[35] Nakagawa N, Ishida M. Performance of an internal direct-oxidation carbon fuel cell and its evaluation by graphic exergy analysis. Ind Eng Chem Res $1988 ; 27: 1181-5$.

[36] Liu RZ, Zhao CH, Li JL, Zeng FR, Wang SR. A novel direct carbon fuel cell by approach of tubular solid oxide fuel cells. J Power Sources 2010;195:480-2. 
[37] Konsolakis M, Marnellos GE, Al-Musa A, Kaklidis N, Garagounis I, Kyriakou V. Carbon to electricity in a solid oxide fuel cell combined with an internal catalytic gasification process. Chinese J Catal 2015;36:509-16.

[38] Li C, Shi YX, Cai NS. Performance improvement of direct carbon fuel cell by introducing catalytic gasification process. J Power Sources 2010;195:4660-6.

[39] Wu YZ, Su C, Zhang CM, Ran R, Shao ZP. A new carbon fuel cell with high power output by integrating with in situ catalytic reverse Boudouard reaction. Electrochem Commun 2009; 11:1265-8.

[40] Chien AC, Siengchum T, Chuang SSC. Investigation of Boudouard Reactions on Carbon-based Solid Oxide Fuel Cells by Transient Techniques. ECS Trans $2011 ; 33: 75-85$.

[41] Nabae Y, Pointon KD, Irvine JTS. Ni/C Slurries Based on Molten Carbonates as a Fuel for Hybrid Direct Carbon Fuel Cells. J Electrochem Soc 2009;156:B716-20.

[42] Jiao Y, Zhao JH, An WT, Zhang LQ, Sha YJ, Yang GM, et al.. Structurally modified coal char as a fuel for solid oxide-based carbon fuel cells with improved performance. J Power Sources 2015;288:106-14.

[43] Jiao Y, Tian WJ, Chen HL, Shi HG, Yang BB, Li C et al.. In situ catalyzed Boudouard reaction of coal char for solid oxide-based carbon fuel cells with improved performance. Appl Energ 2015;141:200-8.

[44] Jewulski J, Skrzypkiewicz M, Struzik M, Lubarska-Radziejewska I. Lignite as a 
fuel for direct carbon fuel cell system. Int J Hydrogen Energ 2014;39:21778-85.

[45] Antunes R, Skrzypkiewicz M. Chronoamperometric investigations of electro-oxidation of lignite in direct carbon bed solid oxide fuel cell. Int $\mathbf{J}$ Hydrogen Energ 2015;40:4357-69.

[46] Xu K, Chen C, Liu H, Tian Y, Li X, Yao H. Effect of coal based pyrolysis gases on the performance of solid oxide direct carbon fuel cells. Int J Hydrogen Energ 2014;39:17845-51.

[47] Dudek M, Tomczyk P, Socha R, Hamaguchi M. Use of ash-free "Hyper-coal" as a fuel for a direct carbon fuel cell with solid oxide electrolyte. Int J Hydrogen Energ 2014;39:12386-94.

[48] Fu CJ, Chan SH, Ge XM, Liu QL, Pasciak G. A promising Ni-Fe bimetallic anode for intermediate-temperature SOFC based on Gd-doped ceria electrolyte. Int J Hydrogen Energ 2011;36:13727-34.

[49] Wang X, Li K, Jia LC, Zhang Q, Jiang SP, Chi B, et al.. Porous Ni-Fe alloys as anode support for intermediate temperature solid oxide fuel cells: I. Fabrication, redox and thermal behaviors. J Power Sources 2015;277:474-9.

[50] Ishihara T, Yan JW, Shinagawa M, Matsumoto H. Ni-Fe bimetallic anode as an active anode for intermediate temperature SOFC using $\mathrm{LaGaO}_{3}$ based electrolyte film. Electrochim Acta 2006;52:1645-50.

[51] Chick LA, Pederson LR, Maupin GD, Bates JL, Thomas LE, Exarhos GJ. Glycine-nitrate combustion synthesis of oxide ceramic powders. Mater Lett 1990;10:6-12. 
[52] Bai YH, Liu J, Gao HB, Jin C. Dip coating technique in fabrication of cone-shaped anode-supported solid oxide fuel cells. J Alloy Comp 2009;480:554-7.

[53] Bai YH, Liu J, Wang CL. Performance of cone-shaped tubular anode-supported segmented-in-series solid oxide fuel cell stack fabricated by dip coating technique. Int J Hydrogen Energy 2009;34:7311-5.

[54] Zhang HQ, Zhao DD, Tang D, Zhang T, Shao ZP. Development of nickel-iron bimetallic catalytic layer for solid oxide fuel cells: Effect of citric acid. Int J Hydrogen Energ 2014;39:9467-72.

[55] Lin YB, Zhan ZL, Liu J, Barnett SA. Direct operation of solid oxide fuel cells with methane fuel. Solid State Ionics 2005;176:1827-35.

[56] Liu J, Su WH, Lv Z, Ji Y, Pei L, Liu W, et al.. A rapid sealing method for solid oxide fuel cell using metal conductive adhesive. Chinese Patent: CN02133049.2.

[57] Xie Z, Zhu W, Zhu BC, Xia CR. $\mathrm{Fe}_{x} \mathrm{Co}_{0.5-x} \mathrm{Ni}_{0.5}-\mathrm{SDC}$ anodes for low-temperature solid oxide fuel cells. Electrochim Acta 2006;51:3052-7.

[58] Park HC, Virkar AV. Bimetallic (Ni-Fe) anode-supported solid oxide fuel cells with gadolinia-doped ceria electrolyte. J Power Sources 2009;186:133-7.

[59] Leng YJ, Chan SH, Khor KA, Jiang SP. Performance evaluation of anode-supported solid oxide fuel cells with thin film YSZ electrolyte. Int J Hydrogen Energy 2004;29:1025-33.

[60] Ding J, Liu J, Guo WM. Fabrication and study on $\mathrm{Ni}_{1-x} \mathrm{Fe}_{x} \mathrm{O}-\mathrm{YSZ}$ anodes for intermediate temperature anode-supported solid oxide fuel cells. J Alloys Compd 
2009;480:286-90.

[61] Konsolakis M, Kaklidis N, Marnellos GE, Zaharaki D, Komnitsas K. Assessment of biochar as feedstock in a direct carbon solid oxide fuel cell. RSC Adv 2015;5:73399-409.

[62] Kaklidis N, Kyriakou V, Garagounis I, Arenillas A, Menendez JA, Marnellos GE, et al.. Effect of carbon type on the performance of a direct or hybrid carbon solid oxide fuel cell. RSC Adv 2014;4:18792-800.

[63] Chien AC, Chuang SSC. Effect of gas flow rates and Boudouard reactions on the performance of Ni/YSZ anode supported solid oxide fuel cells with solid carbon fuels. J Power Sources 2011;196:4719-23.

[64] Virkar AV, Chen J, Tanner CW, Kim JW. The role of electrode microstructure on activation and concentration polarizations in solid oxide fuel cells. Solid State Ionics 2000;131:189-98. 